\title{
Government control of cross-border MA: legitimate regulation or protectionism?
}

Heinemann, Andreas

DOI: https://doi.org/10.1093/jiel/jgs030

Posted at the Zurich Open Repository and Archive, University of Zurich ZORA URL: https://doi.org/10.5167/uzh-65599

Journal Article

Originally published at:

Heinemann, Andreas (2012). Government control of cross-border MA: legitimate regulation or protectionism? Journal of international economic law : JIEL, 15(3):843-870.

DOI: https://doi.org/10.1093/jiel/jgs030 


\title{
GOVERNMENT CONTROL OF CROSS-BORDER M\&A: LEGITIMATE REGULATION OR PROTECTIONISM?
}

\author{
Andreas Heinemann*
}

\begin{abstract}
Recently, much light has been shed on the conditions under which Foreign Direct Investment (FDI) inflows are beneficial to the receiving state and its citizens. However, when inbound FDI takes the form of cross-border mergers and acquisitions (M\&As, as opposed to 'greenfield investment'), nations often see their interests affected. Whereas favouring domestic over foreign ownership is restricted to the field of national security in some countries, other governments seem to perceive a general threat with any takeover from abroad. Accordingly, an increasing number of states have installed control mechanisms that attempt to screen cross-border takeovers for their compatibility with national interests. This article consists of both a legal and an economic analysis. First, an inventory is made of national policy instruments that provide a nation with control over the takeover of domestic firms by foreign investors. Second, we examine the extent to which national control instruments are compatible with international economic law, including regional integration agreements. Third, we discuss the economic reasons for cross-border M\&A and the reasons for government control of these transactions. Consisting of both normative and positive elements, the analysis is not restricted to questioning whether and why governments should provide for state control of cross-border takeovers; rather, it extends to the actual motivation behind state interference. The article concludes with several policy proposals.
\end{abstract}

\footnotetext{
* Professor at the University of Zurich, Faculty of Law. E-mail: andreas.heinemann@rwi.uzh.ch. This research was presented at the Global Fellows Forum of NYU School of Law's Hauser Global Law School Program. The author's thanks go to the Program Director Richard D. Stewart as well as to Harry First for his constructive feed-back as a commentator. For their criticism and encouragement throughout the fellowship, I would especially like to thank my co-fellows Antonina Bakardjieva Engelbrekt, Christian Hofmann, Tsvi Kahana, Ola Mestad, Federico M. Mucciarelli, Christoph G. Paulus, Ingo Venzke, Fouad Zarbiev, Tal Zarsky, and Josephine van Zeben.
} 


\section{NATIONAL REGULATIONS ON THE CONTROL OF CROSS-BORDER TAKEOVERS}

In recent years, government interventions directed against the takeover of domestic firms by foreign companies have become increasingly more frequent. This does not appear to be linked to the financial and economic crisis but is instead a general phenomenon. Apparently, many states see their interests affected when a domestic firm falls into the hands of a foreign investor. In addition, tensions have increased with the rise of Sovereign Wealth Funds (SWFs). Even states that are rather permissive with foreign investment ask whether freedom of investment should extend to state-controlled entities. An increasing number of states have adopted legal instruments with which to control cross-border takeovers. In place of an introduction, we will provide an overview of various control mechanisms that have been implemented in certain countries.

\section{A. USA}

In the USA, the Exon Florio Amendment of 1988 provides a mechanism with which to control foreign investment, ${ }^{1}$ whereby the President may prohibit a cross-border takeover if it threatens national security. The authority to administer the Exon Florio Amendment rests with the Committee on Foreign Investment in the United States (CFIUS), which is chaired by the Secretary of the Treasury. ${ }^{2}$ The CFIUS has the competence to impose conditions or modifications necessary for the protection of national security on a takeover. For this purpose, mitigation agreements may be made that oblige the investor to divest certain parts of the target company or to provide for other commitments, such as continuing the supply of products of strategic importance. Since 1993, an investigation by the CFIUS has been mandatory in a cross-border takeover if the acquirer is a state-controlled entity (Byrd Amendment ${ }^{3}$ ).

Under Exon Florio, there is neither a reporting obligation on the investor nor a limitation period on the government. However, once a review has been initiated by the government or a notice of the transaction has been filed by the parties, an investigation has to be completed within 30-75 days; the President has another 15 days for the preparation of his/her decision after a recommendation from the CFIUS. The absence of a limitation period means that an investigation may be initiated several years after a takeover.

${ }^{1}$ Section 721 Defense Production Act of 1950, as amended by section 5021 of the United States Omnibus Trade and Competitiveness Act of 1988. See Jose E. Alvarez, 'Political Protectionism and United States International Investment Obligations in Conflict: The Hazards of Exon-Florio', 30 Virginia Journal of International Law 1 (1989).

${ }^{2}$ CFIUS was founded by President Gerald Ford in 1975. Thus, he reacted to growing concerns within Congress regarding increasing investment flows from OPEC countries.

${ }^{3}$ National Defense Authorisation Act of 1993. 
Despite the absence of a reporting obligation, the parties therefore have an interest in notifying the CFIUS to have legal certainty after expiry of the investigation deadlines.

So far, the President has imposed a prohibition based on Exon Florio in only one case. ${ }^{4}$ In this case, it was feared that the takeover of a supplier to Boeing might give the Chinese acquirer access to the premises of Boeing, including access to projects of military relevance. Recently, a second case of application was imminent when the Chinese investor Northwest NonFerrous International Investment wanted to take over the ailing US mining company Firstgold. In December 2009, the CFIUS recommended the prohibition of the project because a mine of the target company was situated within 50 miles of a naval air station and other military installations. The investor withdrew its project so that the President did not have to make a decision. ${ }^{5}$ However, clear cases such as these are exceptions. Regulatory mechanisms governing investment control have strong preventative effects. Formal prohibitions or even rumours of regulatory problems may compromise a firm's reputation. Hence, if informal contacts uncover a negative attitude from the authorities, investors will often refrain from moving forward. ${ }^{6}$

A threat to national security does not necessarily require a connection with the arms industry; it is sufficient that the takeover affects the ability of the country to defend itself. For example, the CFIUS investigated the transfer of International Business Machines Corporation's IBM's PC business to the Chinese firm Lenovo. Despite initial concerns regarding possible espionage, the transaction was eventually authorized in $2005 .^{7}$ The most well-known cases go beyond a regular application of Exon Florio. The CFIUS had already authorized the takeover of important US harbours by Dubai Ports World (DP World) in 2006. Strong resistance arose from Congress, and DP World found

${ }^{4}$ Decision of 1 February 1990-China National Aero-Technology Import and Export Corporation $(C A T I C)$. Because the takeover had already been implemented, divestiture of the merged entity was imposed; see American Bar Association-Section of Antitrust Law, Review of Foreign Acquisitions Under the Exon-Florio Provision (1992) 151-52.

5 See Matthew C. Sullivan, 'Mining for Meaning: Assessing CFIUS's Rejection of the Firstgold Acquisition', 4 Berkeley Journal of International Law Publicist 12 (2010). It was possibly not just the proximity to military installations, but also the presence of the highly coveted rare earth metals in the mines in question that influenced the negative outcome; see Sullivan, ibid, at 16 .

${ }^{6}$ See the numbers in CFIUS, Annual Report to Congress, December 2011, www.treasury.gov/ resource-center/international/foreign-investment/Documents/2011\%20CFIUS $\% 20$ Annual $\%$ 20Report\%20FINAL\%20PUBLIC.pdf (visited 19 May 2012), 2. From 2008 to 2010, 313 transactions were reported to the CFIUS. And 29 notices were withdrawn during the thirtyday review period. In 93 cases, an investigation was initiated. 13 notices were withdrawn during the investigation. There were no presidential decisions. For earlier cases, see Edward M. Graham and David M. Marchick, US National Security and Foreign Direct Investment (Washington DC: Institute for International Economics, 2006) $57 \mathrm{ff}$.

7 See UNCTAD, World Investment Report 2006 (New York and Geneva, 2006), 242 n 38. The details of the procedure are secret, so no reliable statements regarding potentially agreed upon requirements can be made. 
itself constrained to reselling the US portion of the business that had been taken over. ${ }^{8}$ A comparable situation had previously occurred in 2005, when a takeover of the California oil company Unocal Corporation by the Chinese company China National Offshore Oil Corporation (CNOOC) failed because of general political resistance, not because of a CFIUS recommendation. The takeover of a domestic energy firm by a foreign state enterprise was considered a threat to national security. ${ }^{9}$

After these two affairs, Congress debated whether the Exon Florio rules needed to be tightened. As a result, the Foreign Investment and National Security Act of 2007 (FINSA) was enacted. On the one hand, FINSA has enlarged the scope of the regulation by subjecting the takeover of any 'critical infrastructure' (including energy supply) or 'critical technologies' 10 to a mandatory investigation. ${ }^{11}$ On the other hand, the condition for prohibition or modification continues to be a threat to national security and not to 'economic security', a concept that was also proposed. ${ }^{12}$ However, the number of factors to be considered has been extended. For example, the level of cooperation of the investor's state with US authorities in the field of counter-terrorism may be taken into account. Congress is also involved to a greater extent in decision shaping. The composition of the CFIUS is codified in FINSA, and the participation of numerous agencies aims at strengthening the influence of non-economic considerations. ${ }^{13}$ Indeed, progress has been made regarding transparency of procedures. However,

${ }^{8}$ See Bashar H. Malkawi, 'The Dubai Ports World Deal and U.S. Trade and Investment Policy in an Era of National Security', 7 The Journal of World Investment \& Trade 443 (2006). It is worthwhile to mention that the transaction also covered all British ports. Since no political resistance arose in the UK, the British ports today are run by DP World.

${ }^{9}$ See Joseph Mamounas, 'Controlling Foreign Ownership of U.S. Strategic Assets - The Challenge of Maintaining National Security in a Globalized and Oil Dependent World', 13 Law and Business Review of the Americas 381 (2007), at 403. Soon afterwards, Unocal was taken over by Chevron.

${ }^{10}$ See the definitions in section 721 of the Defense Production Act (50 U.S.C. App. 2170) (a) (6) and (7).

${ }^{11}$ For an overview of the new rules, see George Stephanov Georgiev, 'The Reformed CFIUS Regulatory Framework: Mediating Between Continued Openness to Foreign Investment and National Security', 25 Yale Journal on Regulation 125 (2008).

${ }^{12}$ For tendencies to expand the prohibition conditions, see Matthew R. Byrne, 'Protecting National Security and Promoting Foreign Investment: Maintaining the Exon-Florio Balance', 67 Ohio State Law Journal 849 (2006), at 904; Gaurav Sud, 'From Fretting Takeovers to Vetting CFIUS: Finding a Balance in U.S. Policy Regarding Foreign Acquisitions of Domestic Assets', 39 Vanderbilt Journal of Transnational Law 1303 (2006), at $1327-28$.

${ }^{13}$ Details can be found in Department of the Treasury, Guidance concerning the National Security Review Conducted by the Committee on Foreign Investment in the USA, 73 Federal Register 74567 of 8 December 2008. Cf the annual reports of the CFIUS, www .treasury.gov/resource-center/international/foreign-investment/Pages/cfius-reports.aspx (visited 19 May 2012). 
according to some observers, the uncertainty of the outcome has not been reduced to a satisfactory level. ${ }^{14}$

It has to be mentioned that rules for specific sectors exist outside of Exon Florio. Foreign airlines are not permitted to acquire more than $25 \%$ of domestic carriers. Other restrictions exist in the field of maritime transport, media, telecommunications, banking, fisheries, and nuclear power. ${ }^{15}$ Some US states provide restrictions in the insurance sector and in the purchase of real estate. ${ }^{16}$

\section{B. Canada}

The Investment Canada $A c t^{17}$ subjects non-nationals to a notification obligation if they intend to acquire control of a Canadian firm and if the investment exceeds a certain threshold. ${ }^{18}$ The Minister of Industry (for takeovers in the cultural industry, the Minister of Canadian Heritage) has to authorize such an acquisition. The procedure should not exceed 45 days. The minister will authorize the transaction if it creates a 'net benefit' for Canada. Numerous criteria are taken into consideration, such as the impact on employment, the participation of Canadians, the recourse to Canadian input, the effects on innovation and the effects on competition and compatibility with Canadian industrial, economic, and cultural politics. Often, the investor has to make commitments regarding employment, investment volume, and research and development in Canada; the investor may also have to guarantee a certain participation of Canadians in the management of the target company and the maintenance of the company domicile in Canada. ${ }^{19}$

In 2009, the existing rules were partially relaxed and tightened. The threshold for investors from WTO countries was increased; at the end of a transitional period stretching over several years, it will amount to one billion

${ }^{14}$ See Warren G. Lavey, 'New Regulations for the Committee on Foreign Investment in the United States - Disclosure of Cyber Security Plans and Dealings with Sanctioned Countries Remain Uncertain', 10 Business Law International 253 (2009): 'The new regulations achieve the stated objective of greater clarity in several important areas. In spite of this progress, however, the new regulations still leave much room for uncertainty and opaqueness in areas such as the information requests for cyber security plans and dealings with sanctioned countries.'

15 See World Trade Organization (WTO) - Trade Policy Review Body, Trade Policy Review United States, Document WT/TPR/S/235 of 25 August 2010, Box III.3 behind n 177.

${ }^{16}$ Ibid, n 177.

17 The full name is 'An Act Respecting Investment in Canada', www.ic.gc.ca/eic/site/ica-lic.nsf/ eng/lk51018.html (visited 19 May 2012).

18 The threshold varies annually. In 2010, the value was about 300 million Canadian dollars for investors from WTO members. For investors from non-WTO members (such as the Russian Federation), the threshold amounts to 5 million Canadian dollars in cases of direct acquisition, and 50 million Canadian dollars for indirect acquisitions. The 5- and 50-million-dollar thresholds apply to investors from WTO countries if the target company belongs to the cultural industry.

19 Catherine Pawluch, Kevin Wright and Jonathan Gilhen, 'Canada Enacts Significant Changes to its Foreign Investment Laws', 2 The CPI Antitrust Journal (2010) at 4. 
Canadian dollars. On the other hand, the government may interfere regardless of thresholds and of the acquisition of control if there is a threat to national security. In these cases, an explanatory statement (which is necessary when a takeover is prohibited in the absence of a net benefit) is dispensable. It has to be noted that in 2007, special guidelines were adopted for takeovers by foreign state-owned investors. ${ }^{20}$ The general rules apply, but special consideration is bestowed upon the corporate governance and reporting practices of the investor.

So far, two transactions have been prohibited under the Investment Canada Act. The takeover of the technology company MacDonald, Dettwiler and Associates (MDA) by the US-American competitor Alliant Techsystems was prohibited in 2008. The authorities could not exclude the risk that, after the takeover, the Canadian government's access to the space and satellite technology in question would no longer be guaranteed. ${ }^{21}$ The second prohibition concerned the project of the Australian company BHP Billiton to take over the fertilizer manufacturer Potash. In 2010, the Minister of Industry announced that, without substantial changes, he would not authorize the deal. After that, BHP Billiton withdrew its bid. ${ }^{22}$

Moreover, special legal rules in Canada limit or exclude foreign investment in banking, media, telecommunications, airlines, and railroads.

\section{France}

French law regarding inbound FDI was fundamentally changed in $2005 .^{23}$ There are filing and authorization requirements for the takeover of domestic firms in certain sectors, such as encryption technology, the arms industry, private security systems, and dual-use products. The Minister for Economic Affairs has the power to prohibit takeovers if they are determined to be against national interests. As this power refers only to the economic sectors mentioned, the scope of the written rules is rather narrow. However, the government exerts a de facto control of a general nature. National champions are promoted, and a philosophy of 'economic patriotism' has been developed. ${ }^{24}$ In many cases, the government has informally thwarted the

20 'Guidelines - Investment by state-owned enterprises - Net benefit assessment', www.ic.gc.ca/ eic/site/ica-lic.nsf/eng/lk00064.html\#state-owned (visited 19 May 2012).

21 See Pawluch, Wright and Gilhen, above n 19.

22 See New York Times, 16 November 2010, B 8.

${ }^{23}$ Décret n 2005-1739 du 30 décembre 2005 réglementant les relations financières avec l'étranger et portant application de l'article L151-3 du code monétaire et financier, JORF of 31 December 2005.

${ }^{24}$ Bernard Carayon, Intelligence économique, compétitivité et cohésion sociale, Paris 2003, p 11 and passim, www.ladocumentationfrancaise.fr/rapports-publics/034000484/index.shtml (visited 19 May 2012). Id., Patriotisme économique: De la guerre à la paix économique (Monaco: Editions du Rocher, 2006). 'Economic Patriotism' is a comprehensive approach to the defence of national economic interests. One aspect of the concept is devoted to the protection of domestic business enterprises against foreign takeovers. See Andreas Heinemann, 'Ökonomischer 
takeover of domestic firms by foreign investors and helped to find national solutions. For example, in 2004, the takeover of Aventis by the Swiss company Novartis was prevented, and, instead, a merger of Aventis with the French company Sanofi was encouraged. Likewise, in 2004, the takeover of Alstom by the German company Siemens was blocked, and a solution with the French conglomerate Bouygues was found. In 2005, rumours regarding the acquisition of Danone by PepsiCo triggered strong governmental resistance. In the years 2006-08, the takeover of Suez by the Italian company ENEL was hindered, and a merger of Suez with Gaz de France (GDF) was favoured instead (2006-08). France and Luxembourg each resisted the takeover of Arcelor by Mittal Steel. The merger became effective only after the investor made commitments to the maintenance of headquarters and of production sites. Other examples of government intervention into the takeover of domestic firms could be given.

\section{China}

Economic policy in China relies heavily on industrial policy. Big firms are forged that are expected to be competitive in world markets. For inbound FDI, the 'Catalogue for the Guidance of Foreign Investment Industries' must be consulted. ${ }^{25}$ Long lists enumerate activities in which foreign investment is encouraged, restricted, or prohibited. Applications for authorization have to be filed with the Ministry of Trade (MOFCOM). For many sectors, there are special rules regarding investment requirements. Foreign banks are restricted in their activities, and domestic banks are treated as foreign banks if foreigners hold a total share of $25 \%$ or more. ${ }^{26}$ In the field of life insurance, foreign insurers may hold a maximum share of $50 \%$; there are no restrictions for other insurance activities. ${ }^{27}$ Foreign investors may not acquire shares in media. Regarding general industrial companies, authorizations are practiced restrictively, and a share of less than $50 \%$ is usually granted. Emphasis is placed on the inflow of technology. ${ }^{28}$

Patriotismus' in Zeiten regionaler und internationaler Integration (Tübingen: Mohr Siebeck, 2011).

${ }^{25}$ This catalogue was updated in December 2007; see the Decree No 57 of the State Development and Reform Commission of the Ministry of Commerce of the People's Republic of China, www.fdi.gov.cn/pub/FDI_EN/Laws/law_en_info.jsp?docid=87372 (visited 19 May 2012). See also the 'Regulations for Merger with and Acquisition of Domestic Enterprises by Foreign Investors', effective on 8 September 2006, available at www.yfao .gov.cn/Enshow2.aspx?id=172 (visited 19 May 2012).

${ }^{26}$ WTO, Trade Policy Review - Report by the Secretariat, China, WT/TPR/S/199, 16 April 2008, Part IV, n 149ff.

${ }^{27}$ Ibid, n 187.

${ }^{28}$ See the overview in OECD, Investment Policy Reviews - China, Open Policies Towards Mergers and Acquisitions (Paris: OECD, 2006). MOFCOM provides an internet portal with information for foreign investors; see www.fdi.gov.cn/index.htm (visited 19 May 2012). 
Article 31 of the Chinese Anti-Monopoly Law requires the Anti-Monopoly Authority to apply national security rules when examining a merger. Hence, investment control is built into competition law, an area that is already criticized as being used for purposes of investment control. A prominent example is the Coca Cola case. In 2009, MOFCOM prohibited the takeover of the Chinese juice producer China Huiyuan Fuice Group by Coca Cola, the first prohibition under the new Chinese Anti-Monopoly Law of 2007, by pointing to the anticompetitive effects of the merger. ${ }^{29}$ Since the official reasoning of the Coca Cola prohibition decision is very short, it is difficult to assess allegations of protectionism. ${ }^{30}$ In other cases, MOFCOM has issued merger approvals, although usually only with conditions. ${ }^{31}$

\section{E. Other countries}

Special control of inbound FDI exists in many other countries. For example, in 2009, Germany introduced a general control mechanism for takeovers by investors outside of the EU and EFTA. ${ }^{32}$ The Minister of Economy may prohibit such a takeover if it jeopardizes public policy or the public security of the country. Although investors are not under any reporting requirement and a three-month limitation period runs from the signing of the contract or from the publication of the decision to submit a public offer, the parties have an incentive to make contact with the competent ministry to assure legal certainty. According to reports, the ministry uses this mechanism to obtain guarantees from the acquirer with respect to the investment, such as its duration. $^{33}$

It is worth noting that the openness of a country to takeovers from abroad does not necessarily depend on the absence or the existence of formal investment control mechanisms. For example, British law gives the government the competence to block certain takeovers, whereas Switzerland does not have such rules. Nevertheless, in both countries, there is great openness to inbound FDIs, such as through M\&As. On the other hand, there are countries where foreign takeovers are less welcome, such as Japan, where inbound FDI is the lowest in the OECD. This is not so much due to formal investment control mechanisms, although the Ministers of Finance and Industry

${ }^{29}$ German translation of the decision available at Recht der Internationalen Wirtschaft 2009, 408.

${ }^{30}$ See, for example, the analysis of Britton Davis, 'China's Anti-Monopoly Law: Protectionism or a Great Leap Forward?', 33 Boston College International and Comparative Law Review 305 (2010).

${ }^{31}$ See Dan Wei, 'China's Anti-Monopoly Law and its Merger Enforcement: Convergence and Flexibility', 14 Journal of International Economic Law 807 (2011).

32 Foreign Trade and Payments Act as amended by the law enacted on 18 April 2009 (Federal Law Gazette I 770).

${ }^{33}$ See Hans-Joachim Priess and Bärbel Sachs, Frankfurter Allgemeine Zeitung of 7 October 2009, 23. 
may ban an acquisition if it constitutes a threat to national security. ${ }^{34}$ However, this mechanism has been used only once, in 2008, when the government prevented the British hedge fund The Children's Investment Fund (TCI) from increasing its share in the Japanese energy supplier $\mathcal{F}$-Power from $9.9 \%$ to $20 \% .^{35}$ The main reason for the scarcity of foreign takeovers in Japan is based on factual circumstances, such as the web of cross shareholdings within the Japanese economy. ${ }^{36}$ In Russia, the obstacles to takeovers from abroad consist of both legal mechanisms and factual circumstances. The 2008 Strategic Sectors Law provides for comprehensive governmental control in 42 economic sectors, and the required administrative proceedings for a foreign takeover are opaque by modern standards. ${ }^{37}$

\section{F. Insights}

This brief survey shows that many countries have adopted formal mechanisms to control takeovers from abroad. Some are restricted to specific sectors considered to be of strategic importance, while others apply to all sectors alike. Some address all foreign investors, while others differentiate between investors from either WTO members or non-members or EU/EFTA or non-EU/EFTA member states. Control mechanisms do not only exist in states that have a tradition of heavy-handed interference in the economy and that try to promote national champions. In recent years, many countries have either created regulations or amended existing regulations to permit control of foreign takeovers. This experience has shown that these rules have a strong preventative effect. While there are only sporadic formal prohibitions, there were a high number of takeover projects that were abandoned after concerns were expressed by public authorities.

We must also mention general corporate and capital market laws. The rules governing the transferability of shares, the duties of target companies in the case of a hostile takeover (for example, the legality of creating 'poison pills'), or mandatory offers in the acquisition of control over another company are of great importance for the outcome of a takeover, whether foreign

${ }^{34}$ See Article 27 (5) of the Foreign Exchange and Foreign Trade Act (FEFTA).

${ }^{35}$ Order to TCI to Discontinue Investment in J-Power based on FEFTA, 13 May 2008, www .enecho.meti.go.jp/english/report/080513-1.pdfwww.enecho.meti.go.jp/english/report/0805131.pdf (visited 19 May 2012). See as well Recommendation to TCI, 16 April 2008, www .enecho.meti.go.jp/english/report/080416-2.pdfwww.enecho.meti.go.jp/english/report/0804162.pdf (visited 19 May 2012). The prohibition was in part based on the past practices of the investor.

${ }^{36}$ For details, see OECD, 'Strengthening the Integration of Japan in the World Economy to Benefit More Fully From Globalisation', Paris: OECD, Economics Department Working Paper No 526, 2006, $12 \mathrm{ff}$.

${ }^{37}$ Regarding the investment climate in Russia and the new law of 2008, including the work of the Commission for Foreign Investment Control, see William E. Pomeranz, 'Russian Protectionism and the Strategic Sectors Law', 25 American University International Law Review 213 (2010). 
or domestic. Thus, the legislature may put domestic shareholders in a position to defend themselves against a takeover from abroad. If these tools are granted generously, takeover attempts will often fail. ${ }^{38}$ These and other aspects of corporate and capital market law are too complex to be included in this article. ${ }^{39}$ Another instrument with which a state can use to defend a domestic company against unsolicited takeovers is the issuing of 'golden shares'. Often in the hand of the state, they give their owner a power disproportionate to the actual value of the share. Thus, the holder of golden shares can outvote other shareholders or at least block important decisions of the company in question. ${ }^{40}$

\section{THE REQUIREMENTS OF INTERNATIONAL ECONOMIC LAW}

\section{A. Starting point}

Are states allowed to prevent foreign investors from taking over domestic companies? The principle of sovereignty gives states ample leeway in answering this question. International economic law focuses on the question of the extent to which cross-border investments are protected once they have been made (for example, against expropriation). However, customary international law does not grant rights to investors to be admitted with their investment in another country. ${ }^{41}$

\section{B. Bilateral treaties}

The freedom of states may be restricted by international treaties, such as bilateral investment treaties (BITs). Worldwide, there are 2807 BITs.

${ }^{38} \mathrm{Cf}$ the quote of the (then) European Commissioner for the Internal Market regarding the experience with the EU Takeover Directive (2004/25/EC) of 2004 which was supposed to restrict the possibilities of companies to defend themselves against bidders: 'Too many Member States are reluctant to lift existing barriers, and some are even giving companies yet more power to thwart bids. The protectionist attitude of a few seems to have had a knock-on effect on others. If this trend continues, then there is a real risk that companies launching a takeover bid will face more barriers, not fewer. That goes completely against the whole idea of the Directive' (European Commission, Press Release IP/07/251 of 27 February 2007).

${ }^{39}$ For an analysis, see Federico M. Mucciarelli, Società per azioni e offerta pubblica d'acquisto. Le difese successive contro offerte pubbliche d'acquisto di azioni quotate (Milan: Giuffrè Editore, 2004).

${ }^{40}$ In the EU, golden shares have been declared as widely illegal under the free movement of capital rules, see below II.D.2.

${ }^{41}$ For an overview of international investment law, see Daniel D. Bradlow and Alfred Escher (eds), Legal Aspects of Foreign Direct Investment (Alphen aan den Rijn: Kluwer Law International, 1999); Rudolf Dolzer and Christoph Schreuer, Principles of International Investment Law (Oxford: Oxford University Press, 2008); Thomas Pollan, Legal Framework for the Admission of FDI (Utrecht: Eleven International Publishing, 2006); M. Sornarajah, The International Law on Foreign Investment, 3rd ed. (Cambridge: Cambridge University Press, 2010). 
The list of contracting parties is headed by Germany (136), China (127), and Switzerland (118). ${ }^{42}$ Whereas the scope of these treaties was initially restricted to investments already made in the past, promoting and admitting future investments are becoming increasingly included. ${ }^{43}$ An advantage of a BIT for an investor compared with other fields of public international law concerns dispute settlement; while dispute settlement usually only occurs between states in international treaties, many BITs allow for investor-state disputes.

BITs, however, do not typically include free movement rules. Frequently, 'best efforts' clauses are preferred over binding admission commitments, or a reservation of statutory powers is added subordinating the investment to the entirety of domestic legislation. ${ }^{44}$ More recent types of BITs extend the principles of national treatment and most favoured nation (MFN) to the pre-entry phase of the investment, thus giving foreign investors the right to have their investments treated on an equal footing with nationals or with investors from third states privileged by a treaty. ${ }^{45}$ This extension considerably improves the legal position of an investor. However, countries undertaking such far-reaching commitments regularly include reservations and exemptions with respect to certain sectors. ${ }^{46}$ Exceptions for the protection of national security are added and they may be self-judging, i.e., exempted from an examination within a dispute settlement procedure. ${ }^{47}$ Hence, host states keep control over the admission of foreign investment including the power to protect strategic sectors and to pursue industrial policy.

\section{Multilateral treaties}

There are some multilateral treaties and institutions in the investment field, such as the Multilateral Investment Guarantee Agency (MIGA), whose

42 See the numbers in UNCTAD, World Investment Report 2011 (New York and Geneva, 2011), $100,213-15$. For an analysis of the general issues raised by BITs, see Jose E. Alvarez, 'A Bit on Custom', 42 NYU Journal of International Law and Politics 17 (2009).

${ }^{43}$ See European Commission, Communication - Towards a comprehensive European international investment policy, COM(2010) 343 final of 7 July 2010, 5.

${ }^{44}$ See, for example, Article 2 (1) of the German Model Treaty: 'Each Contracting State shall in its territory promote as far as possible investments by investors of the other Contracting State and admit such investments in accordance with its legislation'.

45 See Articles 3 and 4 of the US Model Bilateral Investment Treaty, available at www.state.gov/ documents/organization/117601.pdf (visited 19 May 2012). For recent trends in the EU see Julien Chaisse, 'Promises and Pitfalls of the European Union Policy on Foreign Investment How Will the New EU Competence on FDI Affect the Emerging Global Regime?', 15 Journal of International Economic Law 51 (2012), 69-73.

${ }^{46}$ UNCTAD, Bilateral Investment Treaties 1995-2006: Trends in Investment Rulemaking (New York and Geneva 2007), 80ff, 142.

${ }^{47}$ UNCTAD, World Investment Report 2010 (New York and Geneva, 2010), 87. But see William J. Moon, 'Essential Security Interests in International Investment Agreements', 15 Journal of International Economic Law (forthcoming), who limits the host state's margin of appreciation in order to guarantee investors sufficient predictability. 
mandate is to promote FDI by insuring investors against political risk. Also a part of the World Bank Group is the International Center for the Settlement of Investment Disputes (ICSID), which provides a forum for the settlement of disputes between host countries and investors. ${ }^{48}$ Other relevant organizations are OECD and WTO whose investment-related aspects shall be sketched in the following.

\section{1. $O E C D$}

Instruments adopted within the OECD contain obligations with a direct link to our subject, namely the admission of inbound FDI. The texts in question are the Code of Liberalisation of Capital Movements and the Code of Current Invisible Operations, both adopted in 1961. The codes are not treaties but are instead texts whose binding effect is based on their quality as a resolution of the OECD Council. OECD member countries commit themselves to gradually dismantling restrictions on the movement of capital and services. A standstill clause prevents member countries from adopting new restrictions. ${ }^{49}$

The OECD codes are the only multilateral instruments with a binding effect aimed at the liberalization of FDI. However, the consequences are limited because these texts only bind OECD members. Apart from that, the liberalization commitments are narrowly construed. For example, 'golden shares' are not considered restrictions in the sense of the codes. ${ }^{50}$ Lists of reservations exist, which allow every state to fine-tune and limit its commitments. As for enforcement, the OECD does not have a dispute settlement mechanism; it relies instead on peer review.

\section{2. $W T O$}

WTO law contains investment-related provisions. The Agreement on Trade-Related Investment Measures (TRIMs) addresses investment insofar as it affects trade. Local content requirements and trade-balancing provisions are prohibited. However, TRIMs is not concerned with the liberalization of cross-border investment. ${ }^{51}$ More relevant for our context is the General

${ }^{48}$ See Christoph Schreuer, The ICSID Convention: A Commentary (Cambridge: Cambridge University Press, 2001).

${ }^{49}$ Moreover, OECD has adopted the Declaration on International Investment and Multinational Enterprises aiming at the coordination of FDI-related measures of OECD member states. The first version dates back to 1976, the most recent one has been adopted in 2011. The text is a (non-binding) code of conduct. With respect to the National Treatment commitments, an 'OECD National Treatment Instrument' has been adopted by which compliance of the Member States can be examined. However, contrary to the Code of Liberalisation of Capital Movements, National Treatment in the sense of the Declaration refers only to the post-establishment phase, so the instrument is not relevant to the subject of takeover control.

50 See OECD Codes of Liberalisation of Capital Movements and Current Invisible Operations A User's Guide, 2007, 23-24, www.oecd.org/dataoecd/21/23/38072327.pdf (visited 19 May 2012).

51 The proposal of the USA and Japan to include more general commitments did not succeed; see John Croome, Reshaping the World Trading System - A History of the Uruguay Round (Geneva: World Trade Organization, 1995) 138ff, 256ff, 308ff. Therefore, the passage in 
Agreement on Trade in Services (GATS). Cross-border services may require a commercial presence in the territory of another WTO member ('Mode 3'). ${ }^{52}$ If WTO members undertake commitments in this sense, rights to market access arise. However, in practice, these commitments do not reach very far. Reservations may be added, including caps on the participation of foreign investors in domestic enterprises and excluding a complete takeover. Moreover, exceptions for the protection of national security apply. Hence, WTO law does not contain a general investment regime. The investment topic was included in the list of the 'new issues' at the Singapore Ministerial Conference (1996) but was removed after the failed Cancún Ministerial (2003). ${ }^{53}$

\section{The multilateral agreement on investment}

Hence, plans for an investment agreement within the WTO have shared the same outcome as that of the initiative for a Multilateral Agreement on Investment (MAI), which has been under negotiation within the OECD since $1995 .{ }^{54}$ The draft text of this agreement extended the principles of national treatment and MFN to the pre-entry phase, i.e., the admission of investment. Investors from the contracting parties would have obtained the right to make investments under the same conditions as domestic investors or as investors from third states privileged by a treaty. Although exceptions existed regarding the legality of state monopolies, golden shares in cases of privatization, or the protection of national security, the MAI would have established clear principles for the admission of cross-border takeovers. However, MAI negotiations failed in 1998. Opponents criticized the loss of national sovereignty in the field of public services and the failure to answer the question of a 'cultural exception'. 55

\section{Results}

This overview shows that international economic law does not provide for important restrictions on states regarding the control of takeovers from abroad. ${ }^{56}$ Exceptions are more recent BITs that refer to national treatment and MFN regarding the admission of investments. More ambitious projects

the preamble expressing the desire 'to facilitate investment across international frontiers' is not implemented in the agreement.

52 Article I (2) c) GATS.

53 Due to the decision of 1 August 2004, the WTO General Council has eliminated the topic 'Investment and Trade' from the work programme of the Doha Development Round, see WTO, WT/L/579, no. $1 \mathrm{~g}$ ). The same fate befell two other 'Singapore issues', namely competition law and public procurement.

54 For the negotiating history see the documentation at www1.oecd.org/daf/mai (visited 19 May 2012).

55 See UNCTAD, Lessons from the MAI, 1999.

${ }^{56}$ Cf UNCTAD, Admission and Establishment, UNCTAD Series on Issues in International Investment Agreements, 2002, 37ff, where the remaining leeway is broken down to six options. 
such as MAI or the inclusion of the investment topic in the WTO systems have not been successful. The existence of the 'Spaghetti Bowl' of BITs is due in no small part to the absence of a comprehensive multilateral investment treaty of universal scope.

\section{Regional Integration Agreements: The example of the EU}

Regional Integration Agreements (RIAs) often contain investment chapters. This is, for example, the case with the North American Free Trade Agreement (NAFTA) that contains detailed rules on investment between NAFTA member states. ${ }^{57}$ The principles of National Treatment and MFN are applied to the admission of investment. ${ }^{58}$ Hence, investors from other NAFTA member states have the right to make investments under the same conditions as nationals (or, respectively, as citizens from third countries privileged by an agreement), including the takeover of domestic businesses. It is expressly stated that no party may impose a requirement according to which a minimum level of equity in a domestic enterprise has to be held by domestic investors. ${ }^{59}$ However, NAFTA member states may enforce restrictions on foreign investment in certain sectors or block such investment completely. Intensive use has been made of this possibility, and the lists of exceptions fill more than one hundred pages. ${ }^{60} \mathrm{~A}$ similar result can be found in MERCOSUR. Whereas the principles of national treatment and MFN apply to the pre-entry phase, many exceptions exist. ${ }^{61}$

\section{The EU Free Movement Rules}

An example of far-reaching investment provisions is the European Union. The Treaty on the Functioning of the European Union (TFEU) contains chapters on free establishment and on the free movement of capital that not only prohibit discrimination but also provide for a general liberalization in this field. The number of exceptions is rather restricted. ${ }^{62}$ The free movement rules restrict the margin within which Member States can interfere with cross-border takeovers. It has to be emphasized that, in 1993, European law extended the free movement of capital rules to investments

57 See NAFTA Chapter 11 on Investment and Seymour J. Rubin and Dean C. Alexander (eds), Nafta and Investment (Alphen aan den Rijn: Kluwer Law International, 1995).

58 Article 1102 section 1 NAFTA: 'Each Party shall accord to investors of another Party treatment no less favorable than that it accords, in like circumstances, to its own investors with respect to the establishment, acquisition, expansion, management, conduct, operation, and sale or other disposition of investments.' Regards MFN, see Article 1103 NAFTA.

59 Article 1102 section 4 (a) NAFTA.

60 See Article 1108 NAFTA with reference to the schedules annexed.

${ }^{6}$ UNCTAD, Investment Provisions in Economic Integration Agreements, 2006, p 22.

62 The EU itself is involved in a number of bilateral and multilateral treaties associated with the investment field. See an overview in European Commission, Provisions on Capital Movements in Multilateral $\mathcal{E}$ Bilateral Agreements of the European Union with Third Parties, 2007, http://ec .europa.eu/internal_market/capital/docs/multi-bilateral-agreements_en.pdf (visited 19 May 2012). 
from countries that are not members of the EU or EFTA. Hence, contrary to other RIAs, investors from any country in the world may invoke EU law to be admitted with their investment in an EU member state. The erga omnes effect is not conditioned on reciprocity, i.e., even investors from states that put obstacles in the way of foreign investors benefit from the EU rules on the free movement of capital. ${ }^{63}$ However, with respect to these third-party countries, the Treaty provides for more exceptions so that, as a result, the EU Member States may be less open to third countries than to other Member States. ${ }^{64}$

\section{EU Case Law}

The European Court of Justice has applied the free movement rules in numerous cases. There are two sets of cases with particular importance to our discussion. In the first group, the Court has established strict principles for national investment control procedures. Often, national procedures are declared illegal because they lack transparency. If authorities are granted broad powers, there is a particular danger that foreigners may be discriminated against. ${ }^{65}$ The decision on the authorization of a certain investment must be based on objective criteria that are known to the investors in advance. The Court will examine whether the legislative goal can be obtained by less restrictive measures, for example, by a system of declarations ex post facto instead of a prior authorization scheme. ${ }^{66}$

The second set of cases concerns 'golden shares'. The European Commission has brought a series of infringement proceedings against EU Member States granting certain shareholders, mostly public authorities, disproportionate power in a corporation and thus violating the principle of 'one share one vote'. The Court has consistently held that such special rights may prevent foreign investors from investing capital in the undertaking concerned. ${ }^{67}$ The infringement may be justified, for example, if it aims to grant Member States 'a degree of influence within undertakings that were initially public and subsequently privatised, where those undertakings are

${ }^{63}$ For details regarding the background of this very open system, see Steffen Hindelang, The Free Movement of Capital and Foreign Direct Investment - The Scope of Protection in EU Law (Oxford: Oxford University Press, 2009).

64 Another restriction follows from the case law of the European Court of Justice (ECJ). Because there is an overlapping of the free movement of capital and the freedom of establishment in the field of FDI, the Court prefers the application of the latter as lex specialis. However, the freedom of establishment only applies to EU citizens. One should think that in the case of investors from third countries, the rules regarding the free movement of capital would apply again (since the freedom of establishment does not apply to citizens from third countries), but the ECJ bars this so that there is no legal protection of FDI from third countries; see ECJ, Case C-492/04 Lasertec (2007) ECR I-3775, para 20ff. This case law is not convincing against the backdrop of the erga omnes effect of the European free movement of capital rules.

65 ECJ, Case C-567/07 Woningstichting Sint Servatius (2009) ECR I-9021, para 33ff.

66 ECJ, Case C-367/98 Commission v Portugal (2002) ECR I-4731, para 50.

${ }^{67}$ See, for example, ECJ, Case C-483/99 Commission v France (2002) ECR I-4781, para 41. 
active in fields involving the provision of services in the public interest or strategic services' ${ }^{68}$ However, the measure has to respect the principle of proportionality, i.e., it must be suitable for securing the pursued objective and must not go beyond what is necessary to attain it. ${ }^{69}$ In most cases, state prerogatives did not meet these conditions and were declared illegal. The only exception is when the Court accepted the Belgian investment control system for its energy infrastructure. According to this system, the competent Minister has the right to oppose any transfer of strategic assets (including energy supply networks) if he/she considers that it adversely affects the national interest in the energy sector. However, the country renounced a system of prior approval, and the authorities have to adhere to strict time limits. The Court held that the measures taken were necessary to guarantee energy supplies in the event of a crisis. ${ }^{70}$

The case law shows that the standards for justification are difficult to meet. ${ }^{71}$ This is also true for national rules directed against takeovers by foreign state investors. One could take the position that the goal of privatization should not be frustrated by the fact that foreign state-owned investors can take over shares of privatized enterprises. The Court has not accepted this argument; rather, it has simply held the view that the rules regarding the free movement of capital do not distinguish between private and public undertakings, whether dominant or not. ${ }^{72}$ In this view, Member States are not even allowed to take measures that are specifically directed against takeovers by foreign state-owned entities. Hence, privatization may be rolled back by cross-border nationalization with the result that the firm in question no longer belongs to its home country but to another state. ${ }^{73}$

In summary, it can be said that national investment control instruments are not illegal per se under EU law but that the requirements for their justification are strict. States have to specify clear goals for the measures in question. These goals must be compatible with the Treaty; for example, they have to be justified by public policy or public security (Art 65 (1) lit. b TFEU) or by other mandatory requirements of public interest. The Treaty contains an exception for the defence industry (Art 346 TFEU). However, a general interest of a state in 'national champions' is not a legitimate goal, nor does the Court accept the argument that the existence of privatized enterprises subject to golden shares is better than renouncing on privatization altogether. An EU Member State has to decide whether it wants to keep a majority share in a certain enterprise. If it renounces on a majority stake, the

\footnotetext{
${ }^{68}$ ECJ, Case C-367/98 Commission v Portugal (2002) ECR I-4731, para 47.

${ }^{69}$ Ibid, at para 49.

70 ECJ, Case C-503/99 Commission v Belgium (2002) ECR I-4809, para 46ff.

71 See, for example, ECJ, Case C-463/00 Commission v Spain (2003) ECR I-4581, para 78.

72 ECJ, Case C-174/04 Commission v Italy (2005) ECR I-4933, para 32.

${ }^{73}$ Confirmed by ECJ, Case C-274/06 Commission $v$ Spain (2008) ECR I-26^, para $43 \mathrm{ff}$.
} 
scope of measures aimed at the maintenance of state control is very restricted.

\section{Consequences for National Investment Control Schemes}

Against this backdrop, it appears doubtful that the control mechanisms in France and Germany ${ }^{74}$ are compatible with the requirements of EU law. Regarding the scheme adopted in Germany, it does not seem convincing as to why the general supervision of all sectors and of all firms regardless of their size should be necessary to defend public policy goals. Moreover, it remains unclear under which conditions the takeover of a domestic firm will be prohibited. It does not appear sufficient to simply point to grounds of 'public policy or security' of the country without precisely specifying what is meant by that. ${ }^{75}$ There is a danger that the competent ministry will use the law as leverage to obtain modifications of certain transactions. Similar criticism may be levelled against the French model. Even if the French legislation is restricted to certain sectors, the criteria by which the government may block or modify certain transactions are not sufficiently clear. It remains to be seen whether the European Court of Justice will accept national interventions based on such broadly defined rules.

\section{EU merger control}

After the European Commission has authorized a merger under the EU Merger Regulation, ${ }^{76}$ the ability of Member States to interfere with that merger project is restricted. They may only take measures 'to protect legitimate interests other than those taken into consideration by this Regulation and compatible with the general principles and other provisions of Community law. Public security, plurality of the media and prudential rules shall be regarded as legitimate interests within the meaning of the first subparagraph'. ${ }^{77}$ This of course also applies to mergers in which a foreign investor takes over a domestic enterprise. This restriction of national sovereignty was relevant in the Endesa case. In that case, the European Commission had authorized the takeover of the Spanish energy provider Endesa by the German supplier E.ON. ${ }^{78}$ The Spanish regulatory authority imposed drastic restrictions, such as the duty to dispose of important assets.

\footnotetext{
${ }^{74}$ See I.C and I.E above.

75 Section 7 (2) n 6 of the German Foreign Trade and Payments Act (see above n 32) adds that a genuine and sufficiently serious threat is required that affects one of the fundamental interests of society. However, this excerpt from ECJ case law does not specify the conditions necessary for an intervention.

${ }^{76}$ Council Regulation (EC) No $139 / 2004$ on the Control of Concentrations between Undertakings, 20 January 2004, OJ L 24/1.

77 Article 21 (4) Merger Regulation. Any other interest (not mentioned in the main text) has to be notified to and recognized by the Commission.

${ }^{78}$ European Commission, 25 April 2006, E.ON/Endesa, COMP/M.4110.
} 
The European Court of Justice held that Spain had violated Art 21 (4) of the Merger Regulation. ${ }^{79}$

Thus, European merger control may be an obstacle to national anti-takeover measures, but only if the EU Merger Regulation is applicable. According to the 'two-thirds rule', this is not the case (although the turnover threshold values are met) if each of the undertakings concerned achieves more than two-thirds of its turnover within one and the same Member State. ${ }^{80}$ Hence, in these cases, Member States are not influenced by the precedence of a European Commission decision. As a result, EU merger control has only a haphazard impact on the legality of national investment control.

\section{THE ECONOMIC BACKGROUND OF FDI AND TAKEOVER CONTROL}

\section{REGULATIONS}

So far, the legal prerequisites that restrict the ability of states to interfere with cross-border takeovers have been discussed. ${ }^{81}$ We now ask the question of whether states are well advised in subjecting the takeover of domestic firms by foreign investors to special control. To answer this question, the economic background of FDI and takeover control has to be explored. First, we will contrast the economic goals of takeover operations with the goals of the state control of inbound FDI. Then, on this basis, the most important aspects of takeover control will be discussed.

\section{A. The Economics of FDI}

In the world of international capital flows, a basic distinction is made between credit transactions, portfolio investments and foreign direct investments (FDIs). Whereas a credit provides loan capital without equity participation, a portfolio investment includes the acquisition of shares. If shares give control over an enterprise in another state, the transaction is categorized as a FDI. On the international level, an operative rule for the distinction between a portfolio investment and a FDI has been adopted: namely, a FDI starts from $10 \%$ of the shares (or the voting power) in another company. ${ }^{82}$ In the takeover context, which is at the heart of our subject, participation rates are normally higher, often involving the acquisition of a majority stake in the target company.

79 ECJ, Case C-196/07 Commission v Spain (2008) ECR I-41*.

80 See Article 1 (2) and (3) Merger Regulation.

81 The rules of international economic law have been given priority. In addition, it would be necessary to analyse national constitutional law governing state interference with business restructuring. This would require a separate analysis for every single country, a task that cannot be accomplished here.

82 International Monetary Fund, Balance of Payments Manual, 5th ed. (Washington, D.C., 2005), n 359ff. 
At the micro-economic level, a FDI has several potential advantages for the investor. The acquisition may permit better access to raw materials (supply-oriented FDI), it may open up new markets (market access-oriented FDI) or it may improve efficiency (cost savings-oriented FDI). ${ }^{83}$ Like all factors of production, capital is scarce. The possible uses of capital compete with one another. If the capital markets are successful, capital is directed to the most beneficial use, and the origin of capital is not relevant. Both domestic and foreign capital contribute to the economic progress alike. This holds true for all forms of capital injection. ${ }^{84}$ On the other hand, FDI may cause damages which often are not reflected sufficiently in economic models. ${ }^{85}$ Consequently, there is generally a positive view of FDI today, which is conditioned on certain prerequisites, for example the existence of a transparent, environment-friendly, and effective legal system which favours and protects competition on the merits. Under these conditions, not only the investor or his country of origin, but also the country of destination will take advantage, regardless of whether it is developed or developing. ${ }^{86}$ Whereas in the 1970s, in the time of the 'New International Economic Order', FDIs in developing countries were assessed critically, most developing countries today try to create a favourable investment climate to attract FDIs while providing for an adequate public policy framework. ${ }^{87}$

\section{B. The normative rationale behind the control of FDI}

\section{Starting point}

If, as a matter of principle, the inflow of capital into a country is a good thing, why should states prevent foreign investors from buying domestic firms? What are possible disadvantages for the country of the firm taken over? In the first place, there may be the fear that the integrated company might cut back on jobs or shift them to another country. R\&D departments

${ }^{83}$ Cf the Ownership, Location and Internalization (OLI) Paradigm of John H. Dunning, 'Trade, Location of Economic Activity, and the Multinational Enterprise: A Search for an Eclectic Approach', in Bertil Ohlin, Per-Ove Hesselborn and Per Magnus Wijkman (eds), The International Allocation of Economic Activity (London: Macmillan, 1977) 395ff.

${ }^{84}$ Sometimes, a political preference for 'greenfield investment' over M\&A is expressed, i.e., the foundation of a new firm or the creation of additional production capacities instead of the takeover of existing capacities. However, the utility of such a preference is not corroborated by economic theory.

${ }^{85}$ See Theodore H. Moran, 'Enhancing the contribution of FDI to development: a new agenda for the corporate social responsibility community, international labour and civil society, aid donors and multilateral financial institutions', 20 (1) Transnational Corporations 69 (2011).

${ }^{86}$ For an overall analysis see Theodore H. Moran, Foreign Direct Investment and Development Launching a Second Generation of Policy Research (Washington DC: Peterson Institute for International Economics, 2011).

${ }^{87}$ In the wake of the financial turbulence since 2007, the discussion on capital controls has intensified again. However, its focus is on short-term capital flows, not on FDI; see, for example, UNCTAD, Development-led globalization: Towards sustainable and inclusive development paths - Report of the Secretary-General of UNCTAD to UNCAD XIII (2011) 55ff. 
might be transferred elsewhere, thereby reducing innovation in the home country. Moreover, there may be the intention to defend sectors of strategic importance, such as the energy sector, where the takeover of domestic firms may create or reinforce energetic dependence. A sell-out of national resources (including raw materials and domestic real estate) may be feared. Other fears concern low environmental standards in the country of the investor, unfair subsidising, the risk of industrial espionage, and insufficient protection of intellectual property. If the investor is state-controlled (e.g. in the case of SWFs or of state-controlled enterprises), the influence of foreign governments is cautioned against. Generally, there is a question as to whether control over domestic enterprises should be given to entities in whose home countries democracy, human rights, equal treatment, and labour laws are not adequately respected.

\section{The impact on employment}

Some of these arguments are of an economic nature and hence must obtain scientific backing in economics, which frankly seems to be lacking. To start with, the impact of cross-border M\&A on jobs in the target country is not clear. ${ }^{88}$ There may be positive effects due to fresh capital. Moreover, enhanced efficiencies and access of the company taken over to new markets may secure domestic jobs. Fears might instead arise in the opposite direction, i.e., if domestic firms make direct investments abroad, parts of the value chain may be transferred to the target's country, including production processes requiring low-skilled workers. However, governments very rarely express concerns when domestic firms acquire other enterprises abroad. Generally, it must be borne in mind that the employment rate in a certain country depends on many circumstances. If employment conditions are not favourable, there will be a loss of jobs anyway, regardless of whether domestic firms are taken over by foreign investors. Instead, there seems to be a complementary relationship between FDI and exports. Intense commercial relations with other countries are frequently solidified by direct investment with a positive effect on jobs. Moreover, empirical data do not corroborate the assumption that there is a significant relationship between the number of jobs in a given company and the nationality of the owner of that company. If anything, those countries that attract few FDIs have greater difficulties in guaranteeing jobs than countries that achieve significant inward FDIs.

${ }^{88}$ See Christian Arndt and Anselm Mattes, 'Cross-Border Mergers and Acquisitions of Multinational Firms - New Firm-Level Evidence', IAW Discussion Paper 62 (Tübingen: IAW, 2010) 18: 'First, the average causal effect of cross-border M\&A on the employment of multinationals is insignificant, but, second, the effect of cross-border M\&A on the multinationals' productivity is positive and significant' (numerous references to economic literature on $\mathrm{p} \mathrm{3).}$ 


\section{Transfer of technology}

Comparable statements can be made with respect to the technology transfer argument. First, regarding the acquisition of technology, a fair amount of money has to be paid. Second, technology transfer is often not one-way; the firm taken over will also benefit from technologies developed by the acquiring company. Finally, the transfer of technology may trigger general spillover effects to the benefit of third parties, i.e., positive externalities. ${ }^{89}$ Therefore, the technology transfer argument can only be accepted in the context of the defence industry, where states can argue that innovation and know-how in this sector should not fall into the wrong hands.

\section{Public policy}

Regarding the respect of human rights, environment protection, industrial espionage, and the protection of intellectual property, the company taken over continues to be subject to all rules applicable in its country. ${ }^{90}$ This statement also applies to the media industry. Often, states ask the (rhetorical) question of whether they should allow the takeover of a domestic media enterprise by an investor controlled by a state that disregards democracy and human rights. The answer should be given through general rules rather than by a case-by-case authorization mechanism. A requirement for the acquisition of a stake in a media enterprise should be the respect of the fundamental values of the target country. This condition blocks takeovers in the media sector by investors controlled by states that, in their law or their practice, do not share these values.

\section{The energy sector}

Frequently, energy markets are used as examples of a sector of strategic importance that must be protected from foreign influence. In this view, domestic ownership of domestic energy providers is a measure to guarantee energy supply, whereas foreign ownership renders the country vulnerable. However, this perspective disregards the cause of the problem, which is that the security of the supply is not jeopardized by the fact that domestic suppliers are owned by foreign companies but rather by the fact that energy resources are situated abroad. This problem is better addressed by a comprehensive energy policy promoting diversification of energy and of supply sources, as well as by better energy efficiency and a strengthening of efforts

${ }^{89}$ See Anselm Mattes, 'International M\&A: Evidence on Effects of Foreign Takeovers', IAW Discussion Paper 60 (Tübingen: IAW, 2010) 3.

${ }^{90}$ UNCTAD, World Investment Report 2008 (New York and Geneva, 2008), 25. Rather, the question should be asked as to which measures should be taken to subject multinational enterprises to minimum standards, e.g., in the field of human rights and environmental protection, when they delve into the legal vacuums of the globalized economy, see Andreas Heinemann, 'Business Enterprises in Public International Law - The Case for an International Code on Corporate Responsibility', in Ulrich Fastenrath et al. (eds), From Bilateralism to Community Interest - Essays in Honour of Fudge Bruno Simma (Oxford: Oxford University Press, 2011) $718 \mathrm{ff}$. 
to save energy. Problems of vertical integration are best dealt with by competition law. The rules on merger control aim, inter alia, at preventing input foreclosure. Applied to the energy markets, this means that the takeover of a domestic energy supplier must not result in the exclusion of other suppliers in that country from the energy supply by the acquiring company.

Thus, competition law may often address relevant problems in a more precise manner than a political takeover control mechanism based on the diffuse criterion of national interest. In the context of cross-border M\&As, the role of competition law has so far been underestimated.

\section{6. $S W F$ s and transparency}

The system of free enterprise is based on private actors pursuing private interests. If actors are not private, and if they pursue other goals, such as general political goals, the system does not work as intended. If the actor is controlled by a foreign state, further concerns arise regarding the strategic and political agenda. The phenomenon of SWFs ${ }^{91}$ has recently attracted special attention since these funds have grown considerably ${ }^{92}$ and because they have increasingly been investing in stocks instead of bonds. ${ }^{93}$ Against this backdrop, a strict control of SWFs has been demanded, such as a participation cap of $20 \% .{ }^{94}$ The International Monetary Fund has been asked to draft guidelines governing the practices of SWFs. Consequently, representatives of 26 states owning one or several SWFs agreed on the Santiago Principles $(2008)^{95}$ that contain best practices for the investment decisions of SWFs. The text is a Code of Conduct that is not legally binding. ${ }^{96}$

${ }^{91}$ See the definition in International Working Group of Sovereign Wealth Funds, Sovereign Wealth Funds - Generally Accepted Principles and Practices ('Santiago Principles'), October 2008, www.iwg-swf.org/pubs/eng/santiagoprinciples.pdf (visited 19 May 2012), 27: 'SWFs are defined as special purpose investment funds or arrangements, owned by the general government. Created by the general government for macroeconomic purposes, SWFs hold, manage, or administer assets to achieve financial objectives, and employ a set of investment strategies which include investing in foreign financial assets. The SWFs are commonly established out of balance of payments surpluses, official foreign currency operations, the proceeds of privatizations, fiscal surpluses, and/or receipts resulting from commodity exports.'

92 See Stephen Jen (Morgan Stanley), 'How Big Could Sovereign Wealth Funds Be by 2015?', www.morganstanley.com/views/gef/archive/2007/20070504-Fri.html\#anchored3a90be-419e11 de-a1b3-c771 ef8db296 (visited 19 May 2012).

${ }^{93}$ An overview of the most important SWFs can be found in the Santiago Principles (above n 91), 31ff.

${ }^{94}$ See, for example, Jeffrey Garten, 'We need rules for sovereign funds', Financial Times, 8 August 2007, 9. The Norwegian state fund did not acquire stakes higher than 5\%; see UNCTAD, World Investment Report 2008 (New York and Geneva, 2008), $35 \mathrm{n}$ 40. The threshold has been raised to $10 \%$; see Norges Bank Investment Management, Government Pension Fund Global - Annual Report 2009, 22.

${ }^{95}$ See above $\mathrm{n} 91$.

${ }^{96}$ See, however, Joseph J. Norton, 'The "Santiago Principles" for Sovereign Wealth Funds: A Case Study on International Financial Standard-Setting Processes', 13 Journal of International Economic Law 645 (2010), at 656, who qualifies the Santiago Principles not even as a code of conduct, but at best as 'quasi-self-regulatory'. 
Of central importance is the principle according to which investment decisions have to be based on economic rather than political considerations. ${ }^{97}$ Exceptions have to be explicitly laid down, and they have to be published. ${ }^{98}$ The operational managers of SWFs must be free from (direct) political influence. ${ }^{99}$

Whereas the Santiago Principles regulate the problem from the perspective of the SWFs, the OECD has adopted guidelines from the perspective of the receiving countries. ${ }^{100}$ The principle of freedom to invest is defended against protectionist tendencies. Exceptions in the interest of national security are possible, but they are narrowly construed. The principles of transparency, predictability, proportionality, and responsibility have to be respected. These standards are to be examined in the usual peer reviews. In the absence of a special enforcement mechanism, peer pressure shall ensure implementation. ${ }^{101}$

An assessment of the SWF problem has to start from the economic observation already made that the inflow of capital is beneficial for a country, regardless of the form or the origin of the capital. ${ }^{102}$ This general principle also holds true for SWFs. How important they are may be illustrated by the fact that, during the late-2000s financial crisis, firms in danger were queuing up to obtain fresh money from these funds. This phenomenon highlights the importance of a national economy to have sufficient capital inflow. Moreover, there is no empirical evidence that investment decisions of SWFs are driven by 'bad' motivations, i.e., to pursue the policy of the originating country by economic means. The raisons d'être of these funds are diverse (e.g. redistribution in favour of future generations, building-up of pension funds, development of infrastructure, stabilization of commodity prices, and hedging of country-specific risks ${ }^{103}$ ), and their investment strategy seems to be profit-seeking rather than political. ${ }^{104}$ Therefore, there is no

97 Santiago Principles (above n 91), at 12: 'A clearly defined policy purpose facilitates formulation of appropriate investment strategies based on economic and financial objectives [...]. The pursuit of any other types of objectives should be narrowly defined and mandated explicitly. A clearly defined policy purpose will also ensure that the operational management of the SWF will conduct itself professionally and ensure that the SWF undertakes investments without any intention or obligation to fulfill, directly or indirectly, any geopolitical agenda of the government.'

98 Principle 19.1.

99 Principles 9 and 16.

100 OECD, 'Guidance on Sovereign Wealth Funds', www.oecd.org/document/19/0,3343, en 2649_34887_41807059_1_1_1_1,00.html (visited 19 May 2012).

101 The European Commission has endorsed the Santiago Principles and the OECD Guidance on SWFs and has consequently renounced further legislative steps that have previously been discussed. See European Commission, A Common European Approach to Sovereign Wealth Funds, 27.2.2008, $\operatorname{COM(2008)~} 115$ final.

102 See above III.A.

103 See International Monetary Fund, Global Financial Stability Report, October 2007, 46-47, www.imf.org/External/Pubs/FT/GFSR/2007/02/index.htm (visited 19 May 2012).

104 See UNCTAD, World Investment Report 2008 (New York and Geneva, 2008), 25. 
good reason for adopting specific takeover control rules with respect to SWFs. ${ }^{105}$ The general rules so far seem sufficient to counter the doubts sometimes raised. The rules regarding merger control will prevent competition from being substantially lessened. In the regulated sectors, the special regulatory rules apply. If the defence industry is concerned, the general reservation in favour of the protection of national security arises.

On the other hand, it is true that in the case of SWFs coming from states that do not meet minimum democratic standards, close attention to their activities is necessary. Transparency should be substantially improved. In many countries, financial regulation obliges investors to simply reveal their identity. These rules have to be strengthened considerably. ${ }^{106}$ However, this does not affect the preference that should be given to the Santiago Principles and the OECD Guidelines over public takeover control mechanisms.

\section{Reciprocity}

Frequently, in the context of business takeovers, reciprocity is postulated. In this view, the opening of domestic M\&A markets should be made dependent on whether the investor's country offers the same favourable investment conditions. This standpoint is of particular relevance for China, Russia, and the Arabic world, whose funds and enterprises act as active investors, but who, at least partially, shield their capital markets from foreign investments. ${ }^{107}$ The postulate of reciprocity has intuitive value since it is an application of the golden rule according to which others should be treated the same way one wants to be treated by them.

However, the argument disregards the fact that inbound FDI increases the capital stock in the country of destination and is therefore beneficial, independent of reciprocity or the distinction between the private or public origin of the capital invested. Correspondingly, the majority of economists think that openness is positive for a national economy even if domestic investors do not have the same market access abroad. For this very reason, in the EU, the

${ }^{105}$ Cf the analyses of Bruce Winfield Bean, 'Attack of the Sovereign Wealth Funds: Defending the Republic from the Threat of Sovereign Wealth Funds?', 18 Michigan State Journal of International Law 65 (2009); Richard A. Epstein and Amanda M. Rose, 'The Regulation of Sovereign Wealth Funds: The Virtues of Going Slow', 76 University of Chicago Law Review 111 (2009); Yvonne Lee, 'The Governance of Contemporary Sovereign Wealth Funds', 6 Hastings Business Law Journal 197 (2009); Joel Slawotsky, 'Sovereign Wealth Funds as Emerging Financial Superpowers: How U.S. Regulators Should Respond', 40 Georgetown Journal of International Law 1239 (2009).

106 See IV.A below.

107 See, for example, Garten (above n 94) with respect to SWFs: 'Reciprocity should be required. If western host countries are going to treat SWFs like any other market participant, the economy of the SWF's home country must be as open as the country in which the SWF aspires to invest. In addition, if a sovereign fund was established because of currency manipulation in the host country that led to excess reserve creation (China), or if it is the result of strident resource nationalism (Russia), or if it is due to monopolistic pricing practices (Saudi Arabia), then consultations should be initiated between the two governments to reduce these policy distortions.' 
rules regarding the free movement of capital are vested with an erga omnes effect that is not conditioned on reciprocity. ${ }^{108}$ Moreover, closer relationships resulting from direct investment may lead to better market access in the country of origin, at least in the medium term.

States not willing to grant advantages unilaterally may invoke the trade policy argument, which holds that the opening up of foreign capital markets may be accomplished more easily if access to one's own capital markets is used as leverage during trade negotiations. However, restrictions on capital inflow will cause welfare losses until a positive outcome of these negotiations is achieved.

\section{Political reasons for public takeover control}

As the economic analysis has shown, there is only a very limited justification for FDI control mechanisms. In sharp contrast to this finding stands the growing popularity of such mechanisms, as discussed in the first part of this article. The most plausible explanation for this discrepancy can be found by a positive analysis on the basis of the public choice approach. ${ }^{109}$ The starting point of this analysis is the idea that politicians, and not just economic actors, maximize personal utility by proposing and taking measures that aim at increasing personal popularity and votes. In this view, politicians propose the use of FDI screening instruments because they think that they will be rewarded by voters for such initiatives. The underlying expectation is that resentments against the 'sell-out' of the domestic economy may be mobilized. Apparently, the population is rather willing to accept 'made in China' than 'owned by China'. 110

The experience in the USA, for example in the Dubai Ports World case, ${ }^{111}$ supports this hypothesis. The CFIUS, the competent body responsible for resolving questions of national security, had already authorized the takeover of major US port facilities. Pressure from Congress (including a 348 to 71 vote against the takeover in the House of Representatives) urged Dubai Ports World to renounce the US part of the transaction. If we assume that the CFIUS was right in rejecting a potential threat to national security, politicians apparently reacted to subliminal hostility among the population against this project and converted resentments against certain investors from abroad into politics. ${ }^{112}$

${ }^{108}$ See II.D. 1 above.

109 See the seminal work of James M. Buchanan and Gordon Tullock, The Calculus of ConsentLogical Foundations of Constitutional Democracy (Ann Arbor: University of Michigan Press, 1962).

${ }^{110}$ Cf Alasdair Keith, 'Outsights on the Five Flows of Globalisation', www.outsights.co.uk/li brary/4/OutsightsOntheFiveFlowsofGlobalisation (visited 19 May 2012), 5.

${ }^{111}$ See I.A above.

${ }^{112}$ See Yiheng Feng, "We Wouldn't Transfer Title to the Devil": Consequences of the Congressional Politicization of Foreign Direct Investment on National Security Grounds', 
A strong mobilization of voters may also be obtained through the job argument. Since the complex economic relationships are not easily intelligible, those politicians who justify protectionist measures with the goal of job security are often rewarded. Those who refer to the welfare-enhancing effect of investment and to the necessity of an overall balance will have more difficulty conveying this more complicated message.

Finally, lobbying plays an important role in the field of investment control. With investment barriers, domestic firms can keep foreign competitors at a distance. The general rule is that restrictions on free trade frequently aim at protecting domestic firms against competitors from abroad. However, what is good for domestic firms may not always be good for domestic consumers.

There are different means by which to counter these mechanisms. The classical method is the allocation of decision-making power to independent authorities. However, this is only of limited effect if the authority's decision is undermined by political interference. Parliament should adopt the general rules which - in a second step - are to be applied by the administrative authorities under the control of the courts. A long-term instrument is public dissemination and communication regarding the advantages and disadvantages of international integration, with special attention to the positive and negative effects of cross-border investments. Some progress in public awareness of the relevant causal relationships can be noted. For example, in the USA, while the takeover of the Rockefeller Center by Mitsubishi and of Columbia Pictures by Sony in 1989 triggered shock waves, the public has become more accustomed to the fact that even well-known enterprises may belong to foreign owners. However, economic crises often lead to opposing tendencies. The insight that openness and exchange are part of the solution, rather than the problem, is easily lost during such periods. ${ }^{113}$

\section{THE INTERNATIONAL FRAMEWORK IN NEED OF REFORM}

Summing up, general control of inbound FDIs cannot be recommended. An exception applies to the field of national security, a term that must be

42 NYU Journal of International Law and Politics 253 (2009), at 255: '[T]he Exon-Florio review process is far too susceptible to outside political forces in the form of overzealous congressional interference with CFIUS and its mission. Rather than address national security concerns, unrestricted political interference based on political gamesmanship and economic protectionism [...] can result in a chilling effect on future investment opportunities.' For an opposing view, see David Zaring, 'CFIUS As a Congressional Notification Service', 83 Southern California Law Review 81, 125 (2009), who considers parliamentary interference an important complement to the work of the competent authorities.

${ }^{113}$ Cf UNCTAD, World Investment Report 2010 (New York and Geneva, 2010), p iii: 'For the recovery to remain on track, private investment is crucial for stimulating growth and employment. Foreign direct investment (FDI) has a major role to play.' 
construed narrowly. ${ }^{114}$ The exception in favour of national security does not justify a general takeover control over sectors declared strategically important, such as, for example, the energy or banking sectors.

\section{A. Increasing transparency}

Reforms are indicated in the field of capital market law. The analysis with respect to SWFs shows a considerable lack of transparency. While it is true that in many countries, an investor has to notify the competent authority when the acquisition of another firm reaches a certain percentage, often only the name and address of the investor has to be revealed. Disclosure rules should be considerably enlarged. The reporting requirements in the USA or in France could serve as an example. In these countries, starting from a participation in the range of $5 \%^{115}$ or $10 \%,{ }^{116}$ investors have to make detailed reports about, for example, their goals for the next six months or whether the acquisition of control or of an influence on the composition of the board of directors is intended. The origin of the capital should be disclosed, including the distribution of debt and equity. However, these requirements are not sufficient. As many countries exist that lack comprehensive public disclosure rules, an audited annual report should be required from the investor that provides information on the overall strategy, on its corporate governance and on the supervision details in its home country. A rating by a recognized rating agency would strengthen the confidence in the report. The Santiago Principles contain important directives that should be generalized beyond the topic of SWFs. As a result, access to direct investment markets should only be granted in exchange of more transparency.

\section{B. Multilateral investment rules}

An increase in transparency would certainly constitute an important step. It is likewise useful to point to the general rules of competition law and to the special rules for regulated industries that invalidate some concerns expressed in the context of cross-border M\&A. However, the core problem identified here can only be addressed by closer international cooperation. There is considerable risk that governments use (or misuse) FDI control

114 See, for example, the EU-US Open Investment Statement, EU-MEMO/08/301, 13 May 2008, http://trade.ec.europa.eu/doclib/docs/2008/may/tradoc_138822.pdf (visited 19 May 2012): 'An open investment environment is compatible with policies that address genuine national security concerns. Measures that address national security concerns should be transparent, predictable and proportionate to the national security concern identified, and precisely circumscribed so as to avoid unduly disrupting the flow of investment.'

115 Section 13 d): US Securities Exchange Act.

116 Article L233-7 VII of the French Commercial Code. 
mechanisms to exert undue influence on cross-border restructuring. ${ }^{117}$ As the analysis has shown, the numerous BITs are not equipped to counter this risk, and the same is true for existing multilateral instruments. What is missing is an international investment treaty that solves the problem of reciprocity and works against the danger of investment protectionism. ${ }^{118}$ The question has to be answered as to whether such a treaty should be conceived as a stand-alone agreement or if it should be anchored within an existing international organization, such as the WTO. In our view, the latter seems preferable because important diplomatic work has already been conducted, and the dispute settlement within WTO works effectively. As the topic of FDI control is at the core of national sovereignty, the high political acceptance of the WTO dispute settlement process is an important reason for the choice of this forum. Hence, the investment topic should be reinserted into the WTO agenda. The state control of cross-border M\&A is an example of the general rule that international problems can only be solved at the international level.

117 Cf UNCTAD, World Investment Report 2010 (New York and Geneva, 2010), 77: '[S]ome countries have set up or reinforced regulatory mechanisms for screening FDI that, in practice, could become protectionist tools.'

118 Cf UNCTAD, World Investment Report 2011 (New York and Geneva, 2011), 110: 'Achieving a balance between the sovereign right to regulate an industry, and the need to avoid investment protectionism, remains a major policy challenge.' See also Syed Tariq Anwar, 'FDI Regimes, Investment Screening Process, and Institutional Frameworks: China versus Others in Global Business', 46 Journal of World Trade 213 (2012), 228. 